\title{
Selective coil embolisation in spontaneous perirenal haemorrhage
}

\author{
Jan Menke
}

Department of Diagnostic Radiology, University Hospital Goettingen, Goettingen, Germany

\section{Correspondence to} Dr Jan Menke, Menke-J@T-Online.de
CrossMark

To cite: Menke J. BMJ Case Rep Published online:

[please include Day Month Year] doi:10.1136/bcr-2013201376

\section{DESCRIPTION}

A 54-year-old man presented with acute right flank pain. He had a history of liver transplantation due to cryptogenic liver cirrhosis 13 years before and reported no trauma. At the last follow-up, his laboratory findings had been normal, including coagulation parameters and haemoglobin $(14.9 \mathrm{~g} / \mathrm{dL})$. On admission the patient was anaemic (haemoglobin $8.4 \mathrm{~g} / \mathrm{dL}$ ), leading to subsequent transfusion of five erythrocyte concentrates. Sonography showed free fluid in the right abdomen. Contrast-enhanced CT revealed a large perirenal haemorrhage, extending from the subcapsular space to the retroperitoneum. Additionally, an active bleeding was visible,
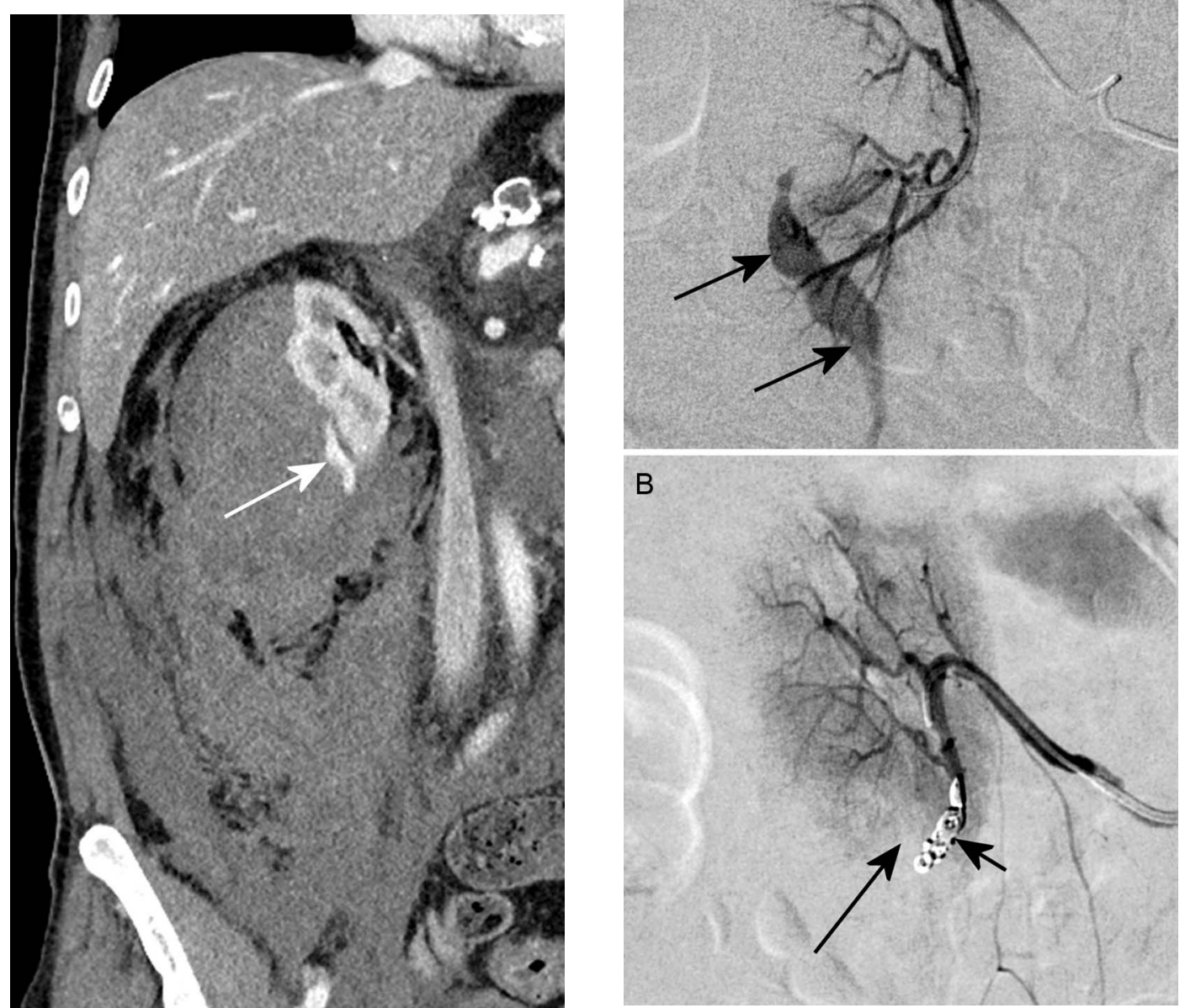

Figure 2 Interventional angiography. Digital subtraction angiography confirmed the active bleeding (A, arrow). After microcatheter-based selective embolisation with four coils ( $B$, short arrow) the bleeding had stopped. Only a small part of the renal parenchyma had been excluded from the circulation by the coiling ( $B$, long arrow). The dark area in the right upper part of (B) is a subtraction artefact, which was evident when viewing the full angiography sequence. 
Spontaneous, non-traumatic renal bleeding into the subcapsular and/or perirenal spaces (Wunderlich syndrome) may have different aetiologies such as neoplasms, vascular diseases and inflammation, and occasionally there is no obvious cause. ${ }^{1} 2$ The diagnosis is well established by CT, which may also show the bleeding source in case of active bleeding. In some patients, the haemorrhage stops by self-tamponade. However, in the present case, the bleeding was still active. Renal angiography with selective embolisation is a minimally invasive method for sparing most of the kidney parenchyma. ${ }^{1-3}$

\section{Learning points}

Acute flank pain with perirenal fluid at sonography may be caused by spontaneous, non-traumatic renal haemorrhage into the subcapsular/perirenal spaces (Wunderlich syndrome).

- Contrast-enhanced CT is well suitable for establishing the diagnosis and for assessing whether there is a persistent active bleeding.

- Persistent active bleeding may be treated by selective renal artery embolisation, while sparing most of the kidney parenchyma.
Contributors $\mathrm{JM}$ is the guarantor of the study and is responsible for the overall content, he also contributed to conception and design of the work, interpreted clinical the data, drafted the article and revised it critically for important intellectual content and approved the final version to be published.

Competing interests None.

Patient consent Obtained.

Provenance and peer review Not commissioned; externally peer reviewed

\section{REFERENCES}

1 Albi G, del Campo L, Tagarro D. Wunderlich's syndrome: causes, diagnosis and radiological management. Clin Radiol 2002;57:840-5.

2 Katabathina VS, Katre R, Prasad SR, et al. Wunderlich syndrome: cross-sectional imaging review. J Comput Assist Tomogr 2011;35:425-33.

3 Pozzi-Mucelli F, Medeot A, Cernic S, et al. Multimodal approach to the endovascular treatment of embolisation or exclusion of the renal arteries and their distal and/or polar branches: personal experience. Radiol Med 2011;116:945-59.

Copyright 2014 BMJ Publishing Group. All rights reserved. For permission to reuse any of this content visit http://group.bmj.com/group/rights-licensing/permissions.

BMJ Case Report Fellows may re-use this article for personal use and teaching without any further permission.

Become a Fellow of BMJ Case Reports today and you can:

- Submit as many cases as you like

- Enjoy fast sympathetic peer review and rapid publication of accepted articles

- Access all the published articles

- Re-use any of the published material for personal use and teaching without further permission

For information on Institutional Fellowships contact consortiasales@bmjgroup.com

Visit casereports.bmj.com for more articles like this and to become a Fellow 